\title{
PROTECTION OF INTELLECTUAL PROPERTY RIGHTS IN THE FIELD OF TELEVISION AND THE INTERNET. THE NOTION OF TELEFORMAT
}

PROTECCIÓN DE LOS DERECHOS DE PROPIEDAD INTELECTUAL EN LA TELEVISIÓN E INTERNET. EL CONCEPTO DE TELEFORMATO

\author{
Halyna Ulianova * \\ Nataliia Baadzhy** \\ Oleksii Podoliev ${ }^{* * *}$ \\ Denys Vlasiuk ${ }^{* * * * *}$ \\ Hanna Chumachenko ${ }^{* * * * *}$
}

\begin{abstract}
The article is devoted to the main issues of protection of intellectual property rights in the field of television and the internet, related to the spread of piracy in the field of copyright and related rights, and to the unlicensed copying of television broadcasts. Moreover, there is an emphasis on the exacerbation of existing problems in the context of the Covid-19
\end{abstract}

\footnotetext{
* Doctor of Legal Science, Professor of Intellectual Property and Corporate Law Department of National University "Odesa Law Academy" (Odesa, Ukraine). https://orcid.org/00000002-2908-6464.ulianova@onua.edu.ua

** Ph. D., Associate Professor of Intellectual Property and Corporate Law Department of National University “Odesa Law Academy” (Odesa, Ukraine). https://orcid.org/0000-00029889-4879. nataliyabaadzhi@gmail.com

*** Ph.D. candidate of Intellectual Property and Corporate Law Department of National University "Odesa Law Academy" (Odesa, Ukraine). https://orcid.org/0000-0002-78053810. Alexeypodolev@gmail.com

**** $\mathrm{Ph}$.D. candidate of Intellectual Property and Corporate Law Department of National University "Odesa Law Academy" (Odesa, Ukraine). https://orcid.org/0000-0002-45663591. vlasykden@gmail.com

****** Ph.D. candidate of Intellectual Property and Corporate Law Department of National University "Odesa Law Academy" (Odesa, Ukraine). https://orcid.org/0000-0003-09252872. litvischenko.an@gmail.com
} 
pandemic and how this affected the industry. This research considers international and national legislation in the field of intellectual law, international experience of various countries, approaches to theory, and problems of implementing existing measures, in order to propose some options for optimizing existing mechanisms. The research methodology use the following methods: formal-legal, historical-legal, comparative analysis, and modeling. The main issues under consideration are the following ones: international broadcasting regulation, the problem of uniform terminology, and prospects for the legal regulation of copyright in television broadcasting. The authors defend the uncompromising protection of intellectual property, highlighting the lack of basic definitions, to propose their own definitions, in order to avoid the weak copyright protection of television broadcasting organizations.

Keywords: Intellectual Property Law, Television, Internet, Television format, Covid-19

Resumen: El artículo está dedicado a las principales cuestiones relacionadas con la protección de los derechos de propiedad intelectual en el campo de la televisión e internet, asociados con la propagación de la piratería en el campo de los derechos de autor y derechos conexos, y con la copia sin licencia de emisiones de televisión. Además, se analiza la exacerbación de estos problemas existentes en el contexto de la pandemia de Covid-19 y cómo esto ha afectado a la industria. Se ha revisado la legislación nacional e internacional en el campo del derecho intelectual, la experiencia internacional de varios países, utilizando enfoques teóricos para resolver los problemas de implementación de las medidas existentes, a fin de proponer soluciones para optimizar los mecanismos existentes. La metodología de investigación se basa en los siguientes métodos: formallegal, histórico-legal, análisis comparativo y modelización. Las principales cuestiones analizadas han sido las siguientes: la reglamentación de la radiodifusión internacional; el problema de la terminología uniforme; y las perspectivas para la regulación legal de los derechos de autor en la radiodifusión televisiva. Los autores defienden la protección intransigente de la propiedad intelectual, destacando la falta de definiciones básicas y proponiendo la suya propia, para evitar la débil protección de los derechos de autor de los organismos de radiodifusión televisiva.

Palabras clave: Ley de Propiedad Intelectual, televisión, internet, formato de televisión, Covid-19 
Summary. I. Introduction. II. Analysis of recent research. III. Results and discussion. III.1. International Legislation in the Field of Protection of Broadcasting. III.2. The Problem of Consonant Terminology. III.3. Prospects for the Legal Regulation of Copyright in Television Broadcasting. V. Conclusions. References.

\section{INTRODUCTION}

The private property belongs to the basic human rights and the foundations of Western civilization along with freedom and respect for private life. This institution became the moral, legal, and material basis for building a modern capitalist society. Of course, intellectual property, as an integral part, played one of the decisive roles in this, because it protected and stimulated discoverers and entrepreneurs to change this world for the better.

Since the second half of the $20^{\text {th }}$ century, two main trends have emerged regarding intellectual property. The first is the strengthening of the protection of intellectual property by companies, the second is the increase in the number of market transactions with intellectual property.

Jackson (2013) describes these trends very accurately in his book Intel Inside:

«By 1974, companies were becoming more jealous of their employees and their intellectual property. Litigation became commonplace, and companies began to use patents to receive significant royalties from their competitors or to enter into large-scale cross-licensing agreements. Patents, trade secrets, and other forms of the intellectual property began to be used by companies as commercial weapons».

Strengthening the protection of intellectual property was influenced by the development of information technologies, the increasing independence of human capital, and the toughening of the struggle of companies for competitive advantages. These factors significantly increased the risk that the results of intellectual work will be outside the company and will be used by third parties who have not invested resources in their development.

This is especially true of the actively developing sphere of the internet and the huge television and radio broadcasting market. The continuous development of the internet leads to explosive growth in the number of internet users around the world, there is a constant race between "internet pirates" and copyright holders. Television viewers are also still generating huge revenues for television companies, but an interesting process of merging the internet and television has begun. In combination with insufficiently developed international and national legislation in the field of 
protection of intellectual property rights on television and on the internet, this leads to the fact that such a right is constantly violated, in particular, through the growth of piracy in the field of copyright and related rights, the spread of the practice of unlicensed copying television formats.

In the context of the current situation in the world-the Covid-19 pandemic and the quarantine measures introduced in connection with itthe population's demand for television and internet services has increased. Thus, according to the marketing report, the time that the population spends watching television programs has grown by forty minutes a day compared to previous years (Influencer Marketing Hub, 2020). There is also an increase in the number of visits to popular web portals such as YouTube, Facebook, TikTok to 15-30 \% (Koeze \& Popper, 2020).

All this testifies to the high relevance and the need to develop and implement mechanisms to protect the rights to private property, in particular to intellectual property.

\section{ANALYSIS OF RECENT RESEARCH}

The rapid development of television and the internet has shown the underdevelopment of international and national legislation on the protection of intellectual property rights in these areas, which encourages scholars and lawyers to contribute to the search and solution of key issues.

Theoretical and practical aspects of the economic essence and features of the use of intellectual property are reflected in the works of some foreign scholars: Cohen, Goto, Nagata, Nelson and Walsh (2002); Bunditsakulchai, Taguchi, and Hitomi (2011); Davenport (1993); Lin and Edvinsson (2010); Hammer and Champy (1993); Hattori, Graniere and Kenkyūjo (2001), and Stefan (2016). In addition to a strong doctrinal base, they also investigated the reasons for strengthening the role of intellectual property and increasing the share of intellectual capital in the activities of enterprises in the world economy.

This work is based, among others, on a thorough article by the team of authors, Kharytonova, Ulianova, Kirilyuk, Simonyan, Baadzhi, Pozova, Grigoryants, Burova and Martyniuk "Problematic issues of determining the legal nature and structure of intellectual property relations arising on the internet" (2015). It reveals the content of the main provisions on the legal regulation of relations in the field of protection of intellectual property rights on the internet, the subject composition and content of such relations. Scholars have suggested paying attention to the definition of the main terms used in cases of infringement of intellectual property rights on the internet, 
the identification of the subjects of such offenses. The specifics of litigation with intellectual property are explained.

Also among domestic researchers there can be distinguished the scientific works of Palladyi (2011), Orlyuk, Svyatotsky and Demchenko (2006), Makarenko and Shemaeva (2014), Grigoryants (2017), Dutchak (2018), which explore the features of the legal regulation of relations in the field of intellectual property.

The work of Zaitseva "Topical issues of the legal protection of television broadcasts and programs as objects of intellectual property rights" (2018) was also used. The author identified the main features of the legal regulation of television broadcasts and programs, their place and role in the system of intellectual property rights, and proposed to enshrine in law a more precise definition of television broadcasts and programs given their differences with other audiovisual works.

The systematization of existing scientific achievements and world experience in the named field, especially in the context of the pandemic, rapid development, changes, and mergers of the internet and television will be the subject of this article.

\section{RESULTS AND DISCUSSION}

\section{III.1. International Legislation in the Field of Protection of Broadcasting}

Since the beginning of the 20th century, technical progress in the field of television broadcasting has developed rapidly, which has given rise to the start of active improvement of legal regulation in this area, as a result of which the international legal regulation of television broadcasting today is a complex system with the Berne Convention ${ }^{1}$ as a basis and international treaties referring to it.

First of all, it should be noted that most states (189 states in total) have ratified the Berne Convention (1886), which establishes the minimum requirements for copyright protection in the legislation of the states parties to the convention. Other treaties in the field of copyright protection and protection in the process of television broadcasting are either special in relation to the Berne Convention (the presence or absence of the status of a special agreement is determined in accordance with Article 20), or they are not such, but only contain separate references to Berne Convention.

\footnotetext{
${ }^{1}$ Supplemented in Paris on 4-V-1896, revised in Berlin on 13-XI-1908, supplemented in Bern on 20-III-1914 and revised in Rome 2-VI-1928, in Brussels 26-VI-1948, in Stockholm 14-VII-1967 and in Paris 24-VII-1971.
} 
The Berne Convention is the most important universal international treaty that protects the rights and interests of authors, as well as regulates and secures the minimum amount of rights granted to the author of a work, which must be established in their legal order by the states parties to the Berne Convention. At the same time, it is important to note that the article of the Berne Convention does not disclose the legal nature of television broadcasting and satellite television broadcasting as technical processes from a legal point of view and does not focus on the application of other norms for the possible interpretation of concepts, in connection with which this problem could be solved either by expanding the scope Berne Convention, or by referring other international treaties to the provisions of the Berne Convention.

The TRIPS Agreement (Trade-Related Aspects of Intellectual Property Rights, 1994), being part of the Marrakesh Agreement Establishing the World Trade Organization (hereinafter, "WTO"), was initially focused on the trade aspects of intellectual property. The TRIPS Agreement broadened and complemented the mechanisms of international copyright protection. Even though the primary purpose of this agreement was to regulate trade aspects, the TRIPS Agreement introduced several provisions supplementing the rules of the Berne Convention (for example, the extension of the Convention's actions to computer programs, databases).

The TRIPS Agreement establishes the national treatment and the most-favored-nation treatment, within the framework of which the minimum amount of legal protection of copyright and related rights objects necessary for each state to comply with is established, the possibility of using effective WTO mechanisms for resolving disputes of the corresponding category, requirements for national legislation on the need to adopt and ensure equal and effective methods of copyright protection for all, the mandatory establishment of such a copyright protection mechanism as compensation for damages, as well as strengthening the copyright protection mechanism by establishing criminal liability for violation of intellectual rights of authors of artistic and literary works in WTO member states.

Thus, although the agreement under consideration is aimed at regulating legal relations in the framework of trade aspects, it is also an addition to the regulation established by the Berne Convention, firstly, directly securing the obligation to comply with the provisions of the Berne Convention for all parties to the agreement, and secondly, supplementing the objects of copyright computer programs and "databases". Concerning television broadcasting, the TRIPS Agreement introduced an important provision (Article 14), according to which broadcasting organizations have the right to prohibit the following actions taken without their consent: 
recording, reproduction of recordings and retransmission through broadcasting channels, as well as public television broadcasting of such recordings. If members do not grant such rights to broadcasting organizations, they provide the copyright holders of the objects of broadcasts with the opportunity to prevent the aforementioned actions, taking into account the provisions of the Berne Convention.

Separately, it should be noted the Copyright Treaty of the World Intellectual Property Organization (1996) (hereinafter the "WIPO Treaty"), which many researchers refer to as the "internet Copyright Treaty": the emergence of the internet in society, the creation and use of new forms of recording work, the emergence of new means communication, the transition of a society to the "digital age" is the reason for constant improvement and the introduction of new provisions governing international copyright protection (Kozyrev \& Leontiev, 2007; Bliznets \& Leontiev, 2009).

Speaking about the relationship between the WIPO Treaty and the Berne Convention, it should be noted that the WIPO Treaty is a special agreement within the meaning of the above Art. 20 of the Berne Convention, maintaining the originally established level of copyright protection, and also not contradicting the article itself. The WIPO Treaty is an attempt to amend the existing international legal regulation and formalize, define the legal relationship concerning the internet system, internet technologies, which, although they should fall under the Berne Convention, are not formally covered by the Berne Convention.

The WIPO Copyright Treaty supplemented the main provisions of the Berne Convention, namely: expanded the scope of copyright provided by the Berne Convention: fixed the exclusive right of the author to communicate to the public for works; limited the scope of copyright to works exclusively expressed in an intelligible form, excluding ideas, methods, concepts from the scope of copyright protection; recognized copyright in computer programs and compilations of data (databases) as rights in literary works.

The adoption of this agreement influenced the development of international regulation of television broadcasting since the granting of the right to communicate to the public of their work to the authors predetermined the author's ability to convey his works through television broadcasting and the internet.

It is necessary to single out a separate group of agreements regulating cross-border television broadcasting.

The first of the above treaties is the European Convention on Transfrontier Television (1989), which is an international treaty regulating the broadcasting of television broadcasts by countries in Europe. 
A separate regulation is dedicated to television commerce, requirements for advertising (duration, form, presentation, placement) and sponsorship are established, according to which a state party to the European Convention on Transfrontier Television must ensure compliance with internationally established technical requirements (parameters) in its state, as well as agree to the rules that apply to broadcasting, sponsorship, and advertising.

Concerning the influence of this document on the development of copyright protection and protection in the television broadcasting system, it should be said that the consolidation of the freedom of reception and retransmission in Europe predetermined the development of the protection of authors' rights to a work broadcast within the framework of television broadcasting.

In addition, Article 10 of the European Convention on Transfrontier Television directly stipulates that cinematographic works should be included in programs only by agreement between the copyright holders for them and the broadcaster and two years after their first showing in cinemas; in the case of cinematographic works produced jointly with a broadcaster, this period is one year.

With the Berne Convention, this document is not a special agreement, although it contains the regulation of many aspects of copyright protection in television broadcasting, which is binding on the countries party to the European Convention on Transfrontier Television.

The European Convention relating to questions on Copyright Law and Neighbouring Rights in the Framework of Transfrontier Broadcasting by Satellite of May 11, 1994 defines broadcasting as the process of transmitting works using a direct broadcast satellite.

Article 1 specifies the difference between the concept of "television and radio broadcasting" in cases where television and radio broadcasting is carried out using a direct broadcast satellite; using fixed satellite services; or the program transmission is encrypted and decryption is provided.

This convention is an attempt to define the concept of television broadcasting, however, the definition given in it is aimed primarily at satellite broadcasting, that is, at a specific method of signal transmission, which makes it impossible to use it for other types of television broadcasting.

The European Convention for the Protection of the Audiovisual Heritage of November 8, 2001, regulates the protection of cinematographic works created. Its main goal is to provide and ensure legal protection of the European cultural heritage (in audio and video form), increase its historical value, create archives for the accumulation and storage of cultural values. 
The Protocol on the Protection of Television Products of November 8, 2001, also extended this convention to television productions. The provisions of the convention provide for the creation of archival bodies for the storage of works in each member state and determine the basic requirements for the protection of these objects.

Thus, we can conclude that the system of copyright protection in television broadcasting today consists of the Berne Convention, which is the fundamental document in the relevant field, as well as special agreements to it - the WIPO Treaty and, regarding European countries - several additional agreements. However, this state of affairs creates many difficulties, since different treaties and conventions are ratified by a different number of countries, with their amendments, which ultimately does not lead to the necessary unification of international legislation, which harms rightsholders.

\section{III.2. The Problem of Consonant Terminology}

There is no single concept of "television broadcasting" in the current system of international regulation of television broadcasting. Some international treaties and recommendations of international organizations contain the specified concepts, but they do not always reflect the specifics of television broadcasting. For example, the International Convention for the Protection of Performers, Producers of Phonograms, and Broadcasting Organizations (1961) (the Rome Convention) defined television broadcasting as the transmission by wireless means of sounds or images and sounds for reception by the public. In the UNESCO Recommendation "On the International Standardization of Statistics in the Field of Radio and Television", adopted on November 22, 1976, "television broadcasting" is defined as broadcasting with the help of moving images of fixed or moving objects with or without sound.

To understand the essence, it is worth turning to television broadcasting as a technical process. And here it is important to pay attention to the fact that the concept of television has changed depending on the stage of technology development (preservation of analog communication channels, a departure from common television standards and the transition to the creation of hybrid analog-digital television systems, the transition to fully digital television systems and the beginning of the merger with the internet).

At the same time, despite the constant changes in the technical side of the television broadcasting process, its technical definition can be derived based on the key features of this process. Such signs are: the presence of two or more special subjects (transmitting and, accordingly, receiving the 
signal), as well as pursuing a special goal - the propagation of the signal for its transmission to the audience. So, Egorov (1997) in his Terminological Dictionary of Television indicates that television broadcasting is "the creation and mass distribution of audiovisual information in a certain system of interaction with the audience." Audiovisual information, in turn, is defined as "any provision of signs, signals, images, sounds or other messages that are not private correspondence at the disposal of the public or individuals through television technology." This concept most correctly reflects the essential features of the television broadcasting process from the technical point of view, in connection with which it will be used here and further in this study in the case of referring to television broadcasting as a technical process.

It is obvious that the technical concept of television broadcasting is not enough for a complete and comprehensive legal analysis of this phenomenon, in connection with which it is necessary to formulate the concept of television broadcasting from a legal point of view. In foreign countries, various approaches to the concept of television broadcasting have been developed. For example, in Germany, the general concept of "broadcasting" covers both "radio" and "television". It is defined in more detail in Section 2 of the Interstate Broadcasting Agreement (1991): "Broadcasting is the provision and transmission for the general public of presentations of all kinds of speech, sound and picture, using electromagnetic oscillations without junction lines or along or by means of a conductor." The definition includes information streams transmitted in coded form for general broadcast as well as broadcast video text. However, this definition is also closer to technical rather than legal and does not reflect the legal aspects of the broadcasting process, which will be discussed below.

Many states to define the concept of television broadcasting refer to the concept of "broadcasting", which, as mentioned above, is in many ways similar to the concept of "television broadcasting". It is noteworthy that often in the national laws of various states one can find successful definitions of the concept of "broadcasting a signal". Thus, in the national legislation of United Kingdom (Copyright Act, 1911), the broadcasting of a work is understood as "the communication through wireless communication of images, sounds or other data, the reception of which can be carried out by lawful actions or which are created for subsequent communication to the public" (Bentley \& Sherman, 2004). It is worth noting that this definition contains both the technical characteristics of the broadcasting process and its legal aspects: an indication of the legality of actions during reception, as well as the use of the legal term "bringing to the public". 
In Japan (Broadcast Act, 2010), the term "broadcasting" means the transmission (including transmission using telecommunications equipment) of signals and sounds to transmit them to the public. This definition contains markedly fewer characteristics of the broadcasting process compared to the definitions in Germany or the UK.

In fact, in the above examples, the complex technical definition is "cut down", and a general similar concept is derived, the main content of which is the organization of the transmission of signal and sounds from one special subject to another to transmit the specified signal to the public. An analysis of the above definitions shows that although a "technical" approach to understanding the broadcasting process prevails in the laws of these states, states are making attempts to reflect, when formulating the corresponding concept, including its essential aspects from a legal point of view. It is fair to ask whether any of the above definitions is sufficient for a complete and comprehensive legal regulation of television broadcasting?

It seems that the concept of "television broadcasting", which could be used at the international level by all subjects interested in participating in the relevant international legal regulation, regardless of their level of technical development, should: contain general technical characteristics of the television broadcasting process, remain relevant with the further development of forms and types television broadcasting, and also contain an indication of the subjects of legal relations arising in connection with the implementation of television broadcasting.

At the same time, television broadcasting as a legal concept (in the context of international law) has the following features.

Firstly, these are specific subjects, in the process of interaction of which a legal relationship arises related to television broadcasting. Such subjects are: (i) a signal-receiving organization that broadcasts a received signal to a certain territory; (ii) an organization that sends a signal to the territory of another state; and (iii) the organization that is the owner of the transmitted signal (owner of the copyright object). In this case, the transmitted signal acts directly as the subject of legal relations for signal transmission. The absence of at least one of the listed subjects will indicate the absence of legal relations related to television broadcasting.

Secondly, this is the content of relations arising between the subjects of television broadcasting - the direction of audiovisual information to the territory of another state. As mentioned above, the concept of "television broadcasting", taking into account the constantly improving broadcasting technologies, should take into account all possible methods and means of transmitting information: they can be conductors, wireless communications, 
including using electromagnetic waves, using telecommunications equipment, or any differently.

Thirdly, the distinctive feature of television broadcasting is the purpose of transmitting information, to receive it and then bring it to the public. So, it is obvious that in the absence of the public (an indefinite circle of persons-recipients of information), for example, when transmitting information to a specific individual or a specific group of persons, this process will not be television broadcasting.

Fourthly, as a feature of television broadcasting, one can single out the specifics of the object transmitted by the above methods, which is the object of copyright and related rights.

Taking into account the above signs, in the context of international law, the concept of "television broadcasting" can be formulated as followsthese are relations arising on a contractual basis between two specialized organizations (receiving the signal and sending it), the main content of which is the direction by wire, as well as through wireless communication, including using electromagnetic waves, using telecommunication equipment or in any other way of audiovisual information, which is the object of copyright and related rights, to the territory of another state to receive it and then bring it to the public for a fee or without it.

Based on the results of the analysis, it can be concluded that today in international legal regulation, as well as in the normative acts of national legal systems, there is no unified understanding of the television broadcasting process, and there is also no generally accepted definition of the concept of television broadcasting. Those definitions that are enshrined in international legal acts and normative acts of national legal systems, in most cases, are a technical description of the television broadcasting process and do not reflect the essential legal features of this concept. We hope that in the near future the international community will make more efforts to unify international treaties in this area and introduce a common terminology, following the example described above, which will be beneficial for all participants.

\section{III.3. Prospects for the Legal Regulation of Copyright in Television Broadcasting}

One of the most pressing issues today in the field of cross-border television broadcasting is the issue of regulating the rights of broadcasting organizations (broadcasting organizations).

The draft new WIPO treaty on the protection of broadcasting organizations, which will be discussed below, defines a broadcasting 
organization as the legal entity that initiates broadcasting and bears editorial responsibility for broadcasting, including the editing of signal-borne programs and however, organizations that deliver their program-carrying signal exclusively via a computer network do not fall under the definition of a "broadcasting organization").

It should be noted that the issue of international regulation of broadcasting organizations' rights has a long history. Thus, for the first time, this issue was raised during the first session of the WIPO Standing Committee on Copyright and Related Rights, held on November 2-10, 1998. The background information on the official WIPO website notes that international rules for the protection of broadcasting organizations have not been updated since the adoption of the Rome Convention (WIPO, 2018). Also, the text on the site draws attention to the fact that this convention was adopted at a time when the internet was not yet invented: "now that perfect digital copies of television programs can be made and transmitted with a few mouse clicks, signal theft has become a headache for broadcasters around the world" (WIPO, 2018). Indeed, an analysis of the provisions of the 1961 International Convention for the Protection of Performers, Producers of Phonograms and Broadcasting Organizations (hereinafter referred to as the "Rome Convention") suggests that its provisions cannot provide an adequate level of protection for the rights of broadcasting organizations. So, for example, following Article 3 of the Rome Convention, "broadcasting" means the transmission by wireless means of sounds or images and sounds for reception by the public. At the same time, the transmission of images and sounds for reception by the public by wireless means refers to terrestrial broadcasting and does not cover Cable and satellite broadcasting, which has already been addressed in the scientific literature (Talimonchik, 2017). Similarly, it does not cover internet television (IPTV, Mobile-TV, etc.).

Thus, today the issue of protecting the rights of broadcasting organizations, taking into account the active development of the internet and the emergence of new threats to broadcasting organizations in this regard, is extremely relevant for international television broadcasting.

For more than twenty years, broadcasting organizations have been trying to achieve an agreement that would ensure the protection of their rights, taking into account new broadcasting technologies, however, there is no agreement among WIPO members on the definitions of the concepts used in the Draft, the list of rights that such organizations should be granted, and other aspects (such as limitations and exceptions, technical protection measures, the term of protection, the legal status of the beneficiaries of protection, application of national treatment). In 2011, the WIPO Standing Committee on Copyright and Related Rights agreed on a work plan to 
develop a new draft treaty that would be acceptable to all or most of WIPO's members (WIPO, 2011). At the same time, the committee set a goal to answer the following key questions in further work on the contract:

- What should be protected. Broadcasters insist on the need to protect all types and methods of signal transmission (including IPTV, Mobile-TV, and other means of signal transmission using the internet). At the same time, some states and public organizations fear the negative consequences of restrictions on internet broadcasting.

- How the broadcast signal should be protected. Broadcasters, again, require a maximum level of protection and suggest the use of language similar to that used in the WIPO internet Treaty. Opponents of this approach point out that the consequence of the introduction of such regulation may be the unintentional blocking of the legal use of television content, as well as hindering the development of technological innovations.

- What rights should be granted to broadcasting organizations. Currently (under the provisions of the Rome Convention), broadcasting organizations have the exclusive right to allow retransmission, recording, and broadcasting of their broadcasts for 20 years. These organizations insist on expanding and updating these rights, first of all, to prevent unauthorized re-transmission of their programs over the internet. Even though in the European Union there is a corresponding regulation, in a large part of the world, retransmission of a television program via the internet without the permission of a broadcasting organization does not violate copyright or related rights.

- What limitations and exceptions should be made, as well as for how long protection should be provided.

Opponents of such changes (WIPO, 2018) point out that the granting of these rights to broadcasting organizations, which, in fact, equates them to the legal status of the copyright holder, will significantly complicate access to television content (due to the need to obtain permission to broadcast not only from the copyright holder, but also from the broadcasting organization), and also partially negates the significance of copyright (giving broadcasting organizations the actual opportunity to determine the conditions for granting the right to use the copyright object). Concerns have also been raised about the possible monopolization of public domain materials (such as expired films or news) that are not subject to copyright.

The most relevant today is the version of the draft treaty on the protection of broadcasting organizations, adopted within the framework of the fifty-third session of the WIPO Standing Committee on Copyright and Related Rights, held on September 21-25, 2020 (hereinafter referred to as the "Draft"). 
The undoubted merit of the Project is to take into account and improve the regulation previously enshrined in the Convention on the Distribution of Program-Carrying Signals Transmitted by Satellite, May 21, 1974 (hereinafter referred to as the "Brussels Convention") and the WIPO Copyright Treaty, as well as a serious step forward in comparison with the contained in the Rome Convention by regulation.

So, for example, the right of broadcasting organizations contained in the Draft to prohibit unauthorized retransmission of their own pre-broadcast signal (including satellite signal) by any means correlates with the provisions of Art. 2 of the Brussels Convention, according to which each Contracting State undertakes to take appropriate measures to prevent the spread on its territory or from its territory of any program-carrying signal by any spreading authority for which the signal transmitted to or passing through a satellite is not intended.

Also, the Draft takes into account the provisions of the WIPO Treaty on technical measures. So, Art. 11 of the WIPO Treaty Contracting Parties shall provide for appropriate legal protection and effective remedies against the circumvention of existing technical means used by authors in connection with the exercise of their rights under this Treaty or the Berne Convention and restricting actions on their works that are not authorized or permitted by authors by law. Similarly, under Art. 12 of the Draft, Contracting Parties shall provide for adequate and effective legal protection against unauthorized: (i) decoding of an encrypted broadcast or circumvention of any technical protection measure having the same effect as encryption; (ii) manufacture, import, sale or any other act that makes available a device or system capable of decoding an encoded broadcast; and (iii) deletion or modification of any electronic rights management information used to protect the rights of broadcasting organizations ${ }^{2}$.

Besides, in fact, borrowed from the WIPO Treaty (Article 12 of the WIPO Treaty) are the provisions of Art. 12 of the Draft on Rights Management Information Obligations. Thus, following the said article, the Contracting Parties shall provide appropriate and effective remedies against any person who intentionally commits any of the following acts, knowing or - in the case of civil remedies - having reasonable grounds to know that such an act would induce a violation any right covered by this Agreement will allow such violation, facilitate or conceal it: (i) deletion or modification of any electronic rights management information without authorization; and (ii) distributing or importing to distribute fixations of broadcasts, relay or communicating to the public, or broadcasting or making available to the

\footnotetext{
${ }^{2}$ It should be noted that this formulation is not final.
} 
public of fixed broadcasts, without authorization, knowing that electronic rights management information has been, without authorization, removed or altered in broadcasts or signals before broadcasting.

It seems that taking into account the provisions of previously concluded international treaties, including treaties containing the regulation of the most actively developing areas in television broadcasting (satellites and the internet) is a positive trend.

At the same time, one cannot but draw attention to the fact that the purpose of the Project is to protect precisely related rights, while the object of protection under the Project is the signals carrying the program broadcast by the broadcasting organization. Also, the copyright of broadcasting organizations is not affected by the Project.

In the author's opinion, full-fledged protection of the rights of broadcasting organizations is impossible by ensuring the protection of only related rights. Thus, broadcasting organizations are often not only intermediaries between copyright holders and the audience, but also the authors of the results of intellectual activity: for example, broadcasting organizations can be the authors of Teletext, creators of the television format, the issues related to which were discussed in Chapter 2 of this work, the headings "TV shop" etc. In such cases, it appears that broadcasters should have copyright in the content they create, and the Draft should include appropriate provisions granting broadcasting organizations the rights of authors of works.

However, the existing cases in Ukraine of prosecution for, in fact, copying a teleformat without its prior purchase, indicate that the plaintiffs in the statement of claim refer to the violation of copyright in the audiovisual work, and not to the violation of related rights to broadcast (programs) of broadcasting organizations. In particular, the Resolution of the Supreme Commercial Court of Ukraine of November 10, 2015 in case $n^{\circ}$ 910/19751/14 satisfied the claim of Novy Channel LLC and recognized the violation of its copyright to the audiovisual work-television program "Inspector" and the literary work-Typical script of the television program "Inspector", by releasing the television program "Inspector Freymouth" LLC Television and Radio Company "Studio $1+1$ ". In arguing its own decision, the Court referred to some key elements of the television program "Inspector", which were obviously the same in both programs: the image of the presenter (style, subject-glove or handkerchief, etc.), the nature of inspections (suddenness, openness, implementation against the owner's will, etc.) transfer, the final result (providing the appropriate plate) and others.

Thus, the optimal solution to the question "what violation of the right to refer to, if there was an unlicensed copying of teleformat-copyright 
(audiovisual work) or related (to the broadcast (program) of broadcasting organizations)?", will be a reference to copyright infringement on audiovisual work. Violation of the related right to broadcast (program) of the broadcasting organizations will most likely be the showing of the original program or program by a television company without obtaining the appropriate permission or license.

So why does Ukraine not suffer from numerous lawsuits by foreign television companies for using their format? Let's analyze the example of the STB TV channel. This television channel has been cooperating with FremantleMedia (owners of many popular television formats since 2009), which includes the possibility of buying and selling television formats for adaptation on Ukrainian television. Among the adapted television programs are such popular ones as "X-Factor" (adaptation of the format "The X Factor"), "Ukraine has talent" (adaptation of the format "Got talent") and others. Thus, in fact, the teleformat is being purchased as an object of intellectual property rights, despite the fact that neither the Ukrainian legislation nor the international level has yet established such a definition.

It is also worth noting that Ukrainian television companies also sell their own television formats abroad. In particular, the Ukrainian Studio "Kvartal-95" sold to the Kazakh "Independent Television Channel" the format of the entertainment project "Comedian Laughs" (UkrInform, 2012). In addition, agreements on the sale of such a television format were also concluded with the Lithuanian Television channel Baltijos Television and the Russian Television channel Russia.

However, despite the above examples, it can be stated that there is a global problem of unlicensed copying of television programs, which in turn leads to attempts to solve this problem by law. An example of a radical fight against television plagiarism is South Korea. The South Korean newspaper JoongAng Daily published statistics showing that the owners of 34 Korean Television programs filed lawsuits against Chinese counterparts. In addition, the Format Recognition and Protection Association supported the allegations of the Korean company, which claimed that the copyright in its talent show had been infringed, as China had released a similar talent show that was almost indistinguishable (Feng, 2018).

Due to the difficulty and protracted nature of international litigation, Korean companies that filed lawsuits rarely received adequate compensation from Chinese companies. Therefore, the National Assembly of the Republic of Korea passed a law amending two regulations related to the protection of intellectual property rights in the field of music and television content. These changes were aimed at strengthening the protection of intellectual property rights abroad - since their entry into force, the Minister of Culture, Sports 
and Tourism of South Korea has received the right to request assistance from the Ministry of Foreign Affairs and other central administrative bodies to combat violations of the above rights (Nan, 2018). Thus, in fact, protection against infringements of intellectual property rights by foreign entities was entrusted to public authorities.

However, although attempts to protect intellectual property rights to teleformat in the courts have not always succeeded, in some countries we can still see cases of awarding compensation to rightsholders. In particular, BBC Worldwide (owners of the "Strictly Come Dancing" format, also known as "Dancing with the Stars") and Italo pubcaster RAI (an Italian television company that acquired the television format and broadcast an adapted television program) filed a lawsuit against Mediaset (Italian private television company) in the Rome Intellectual Property Court because of copying the format "Strictly Come Dancing" without prior purchase, by releasing the television program "Baila!" (Vivarelli, 2011; Spreafico, 2011).

In support of its decision, the Court pointed out that this program and the program broadcasted by the Italian broadcaster that had acquired the teleformat did not have significant structural, narrative and operational differences, the system for selecting candidates and winners, and the costumes, scenery and stage events, etc. The two television programs had obvious similarities. Thus, the copyright infringement on the teleformat was recognized as a set of all the above characteristics (Akhmedov, at al., 2017).

It is worth noting that the need for a radical revision at the international and national levels of the scope of rights granted to broadcasting organizations to bring it into line with modern requirements, including concerning direct rights to a television format, was pointed out back in 1996 at the Seminar of representatives of the Commonwealth of Independent States (CIS) member states on the protection of related rights (UNESCO, 2001): for example, the author of the report, in particular, pointed out the need to provide broadcasting organizations with the right to authorize and prohibit bringing their broadcasts to the public, any fixation of their broadcasts by sound or video recording for any purpose, bringing to the attention of the public with the help of a cable broadcaster or other distribution of its own program-carrying signals, the right to receive a fair remuneration in respect of recordings of their broadcasts, etc.

Thus, one of the disadvantages of the existing Project is the limitation of the rights granted to broadcasting organizations by securing exclusively related rights and the lack of regulation of the copyright of broadcasting organizations.

It is also worth noting that the analysis of the Project does not allow us to conclude that all the goals set by WIPO members have been solved, in 
particular, this Project does not fully take into account the achievement of scientific and technological progress and the widespread use of the internet, and also does not solve the problem of that "digital copies of television programs can be made and transmitted with a few mouse clicks". This problem is connected, first of all, with the proposed wording "broadcast". As stated above, this definition is not understood to include the transmission of a set of signals over computer networks. It seems that the development of technologies and the active penetration of the internet into the field of television broadcasting does not allow ignoring the fact that broadcasting organizations are using technology for transmitting information over computer networks, and therefore formulations suggesting that this method of transmitting information be removed from the regulation of the contract is unacceptable. There is no doubt that the rights of broadcasting organizations should be protected regardless of the signal transmission method. However, it should be noted that when adopting the final version of the agreement, the comments of the opponents of the Project should also be taken into account: in particular, the agreement should not provide broadcasting organizations with the opportunity to deliberately or accidentally block the legal use of the content, as well as artificially hinder the development of technological solutions. Thus, in this part, the main goal of WIPO members today should be to find a reasonable balance of interests of broadcasting organizations and consumers of television content, in which, on the one hand, protection will be provided taking into account all possible ways of sending a signal, on the other hand, the introduced regulation will not excessive and will not allow broadcasters to abuse their opportunities.

It is necessary to pay attention to the fact that the Project does not solve all the problems that exist today in the relevant area, and are caused, first of all, by the active penetration of the internet into the broadcasting sphere.

So, for example, many problems are associated with online broadcasting of works by the authors of the works themselves if they independently decided to distribute their work (for example, a musical work) through online broadcasting on the internet (it is obvious that this distribution may entail losses for a broadcasting organization whose audience will instead use content provided by the author instead of paying through the organization). Online broadcasting (online broadcasting, stream) has become widespread on platforms such as Facebook, YouTube, Periscope, or Twitch, on which any user has the right to provide any work to his audience. At the same time, the use of these platforms and the entire specificity of the distribution of works is not regulated by either international or national legislation, which requires prompt intervention and regulation of the use of these reforms. It should be noted that in connection with the active 
distribution of these services, some researchers already call the Project "YouTube Agreement", since it acts in the interests of this service (Ress, 2017).

An example is the high-profile case related to the live stream in 2015. The case is related to the coverage of a boxing match between boxers Floyd Mayweather Jr. and Manny Pacquiao (Wagstaff, 2015). In this case, there was a broadcast of "streaming" video in real time from one user to the audience through applications like Meerkat and Periscope. These programs allow anyone with a smartphone to broadcast live video to their subscribers on social networks, everything: ordinary life activities (for example, a person walking down the street), events (for example, events, and protests), content redistribution (for example, streaming popular cable television show). In the case in question, the fight was broadcast by subscription broadcasters HBO and Showtime. At the same time, the internet offered the opportunity to watch an online battle for free in "alternative ways" by going to third-party sites to promote their products and raise their rating. Providing access to the online broadcast of the match without acquiring broadcasting rights led to losses for broadcasting organizations broadcasting the match, which was confirmed by the court and indicated that there was a violation of the broadcasting organization's rights in this case and the need for additional settlement of issues in this area.

At the same time, the regulation proposed by the Draft is not designed to resolve such disputes and could not help broadcasters in such a situation.

Based on the results of the paragraph, the following conclusions can be drawn. The project is aimed at protecting related rights of broadcasting organizations, while at the present stage of technology development, according to the author, broadcasting organizations need to protect not only related rights but also copyright. However, there are no provisions in the Draft for the protection of the copyright of broadcasting organizations.

Several existing problems have not yet been resolved by the Project. In particular, the protection of the rights of broadcasting organizations is not fully ensured when broadcasting via the internet (which is due to the general focus of the Project on traditional broadcasting means), and the issues of online broadcasting of works, the right to broadcast of which have been transferred to broadcasting organizations by the authors themselves, remain unresolved.

In summing-up, we can say that the adoption of the final version of the Project looks extremely unlikely, and the history of the development of this issue allows us to conclude that the speed of development of scientific and technological progress is significantly ahead of the speed of discussion by WIPO members of the Project. It is possible that at the time of the adoption of the final version, the organization of the television broadcasting process will change so much that the text of the agreement will become irrelevant. 


\section{CONCLUSIONS}

During the elaboration of the topic of protection of intellectual property rights in the field of television and the internet, a number of problematic issues were identified and the best options for their solution were proposed, in particular:

1. The existing system of international treaties and agreements has a long history of creation, is vast, confusing, and insufficiently effective. This state of affairs creates many difficulties since different treaties and conventions are ratified by a different number of countries, with their amendments, which ultimately does not lead to the necessary unification of international legislation, which harms rightsholders. The international community should pay more attention to this problem.

2. The lack of legislative enshrinement of the concept of "teleformat" at the international and national levels causes certain difficulties, in particular, in the protection of infringed copyright in court. Therefore, for the legislative protection of the teleformat, it was proposed to use one of the approaches mentioned in this article.

3. Legal regulation at the international level is vested in the WIPO Committee on Copyright and Related Rights. Despite the regular work and the presence of good practices, there are a number of problematic issues. The problem of the concept of "teleformat" and other rights of television broadcasting organizations is ignored, their creative and intellectual contribution is poorly protected and there are often legal disputes regarding them. Also, the protection of exclusive copyrights is not properly ensured due to the development of streaming services and massive violations by individuals.

In the end, the main problem is that the development of the technical side of communications is so rapid that the international community does not have time to agree and work out common rules of the game for all parties involved, which causes the rights holders to suffer. 


\section{REFERENCES}

Akhmedov, G. A., Voinikanis, E.A., Glazunova, K. D., Zaichenko, N. V., Knyaginina, I. K., Koroleva, I. A., Lipatova, Yu. A., Mityagin, K. S., Smirnova, V. R., Leontiev, K. B., Evdokimova, M. I., Savina, V. S., \& Gurko, A. V. (2017). The main trends in the development of intellectual property rights in the modern world, including new objects of intellectual property rights and global protection. Nevsky IP Law. In https://www.rvc.ru/upload/iblock/85d/Trends_in_Intellectual_Property.pdf.

Bentley, L. \& Sherman, B. (2004). Intellectual Property Law: Copyright. St. Petersburg: Legal Center "Press".

Bliznets, I.A. \& Leontiev, K. B. (2009). Copyright and Related Rights. Moscow: Prospect.

Bunditsakulchai, P., Taguchi, H. \& Hitomi, K. (2011). Compilation of interregional energy SAM of Japan for environmental tax policy evaluation. Central Research Institute of Electric Power Industry, IV, 5-33.

Cohen, W. M., Goto, A., Nagata, A. Nelson, R. R. \& Walsh J. P. (2002). R\&D Spillovers, Patents and the Incentives to Innovate in Japan and the United States. Research Policy, 31(8-9), 1349-1367. DOI: 10.1016/s0048-7333(02)00068-9.

Davenport, T. H. (1993). Business Innovation: Reengineering Work through Information Technology. Boston: Harvard Business School Press.

Dutchak, A. (2018). Prospects for the development of online television through the prism of the evolution of its components. International scientific journal "Internauka", 1(41), 31-36. In http://www.irbis-nbuv.gov.ua/cgibin/irbis_nbuv/cgiirbis_64.exe?C21COM=2\&I21DBN=UJRN\&P21DBN=UJR N\&IMAGE_FILE_DOWNLOAD=1\&Image_file_name=PDF/mnj_2018_1(1)_ -9.pdf.

Egorov, V. V. (1997). Terminological Dictionary of Television: Basic Concepts and Comments. Moscow: Institute for Advanced Training of Television and Radio Broadcasting Workers.

Feng, J. (2018). South Korea calls out Chinese TV producers for frequent plagiarism. SupChina. In https://supchina.com/2018/10/11/society-news-south-koreachinese-tv-producers-plagiarism/.

Germany. (1991). Interstate Broadcasting Agreement. In https://germanlawarchive.iuscomp.org/?p=655\#ToC5.

Grigoryants, G. I. (2017). Piracy as a violation of copyright and related rights on the internet. Odesa: National University "Odess Law Academy". In http://dspace.onua.edu.ua/bitstream/handle/11300/6365/\%d0\%94\%d0\%b8\%d1 $\% 81 \%$ d0\%b5\%d1\%80\%d1\%82\%d0\%b0\%d1\%86\%d1\%96\%d1\%8f\%20\%d0\% 93\%d1\%80\%d0\%b8\%d0\%b3\%d0\%be\%d1\%80\%d1\%8c\%d1\%8f\%d0\%bd\%d1 $\% 86 \% 20 \% \mathrm{~d} 0 \% 93 . \% \mathrm{~d} 0 \% 86 . . p d f ?$ sequence $=4 \&$ isAllowed $=\mathrm{y}$. 
Hammer, M. \& Champy, J. (1993). Reengineering the corporation: a manifesto for business revolution. New York: Harper Business.

Hattori, T., Graniere, R. J. \& Kenkyūjo, D.C. (2001). An empirical analysis of the transition to retail competition in the U.S. electricity industry. Tokyo: Central Research Institute of Electric Power Industry.

Influencer Marketing Hub (2020). Coronavirus (Covid-19) Marketing \& Ad Spend Impact: Report + Stats (Updated August). In https://influencermarketinghub.com/coronavirus-marketing-ad-spend-report/.

Jackson, T. (2013). Intel Inside. The history of the corporation that made the technological revolution of the 20th century. Moscow: Alpina Publisher.

Japan. (2010). The Broadcast Act. In http://www.soumu.go.jp/main_sosiki/joho_tsusin/eng/Resources/laws/pdf/0902 04_5.pdf.

Kharytonova, O. I., Ulianova, G. O., Kirilyuk, A. V., Simonyan, Yu. Yu., Baadzhi, N. P., Pozova, D. D., Grigoryants, G. I., Burova, L. I., Martyniuk, I. V. (2015). Problematic issues of determining the legal nature and structure of intellectual property relations arising on the internet. Scientific works, 1, 159-200. In http://dspace.onua.edu.ua/bitstream/handle/11300/7348/Kharitonova\%20Ulian $\% 20$ Kiril\%20nauk\%20pr17.pdf?sequence $=1 \&$ isAllowed $=\mathrm{y}$.

Koeze, E. \& Popper, N. (2020). The Virus Changed the Way We internet. The New York Times. In https://www.nytimes.com/interactive/2020/04/07/technology/coronavirusinternet-use.html.

Kozyrev, V. \& Leontiev, K.B. (2007). Copyright. Moscow: University book.

Lin, C. Y.-Y. \& Edvinsson, L. (2010). National Intellectual Capital: A comparison of 40 countries. Springer. DOI: 10.1007/978-1-4419-7377-1.

Makarenko, P. D. \& Shemaeva, G. V. (2014). Intellectual property infrastructure in Ukraine: communication aspect. Bulletin of the Kharkiv State Academy of Culture, 43, 97-104.

Nan, H. (2018). TV makers welcome stricter South Korean creative copyright. China Daily. In https://www.chinadaily.com.cn/cndy/201802/08/content_35665755.htm.

Orlyuk, O. P., Svyatotsky, O. D. \& Demchenko, T. S. (2006). Legal regulation of relations in the field of intellectual property: sectoral aspects. Kyiv: PE "Avocado".

Palladyi, M. (2011). Infrastructure of the system of state management in the field of intellectual property: an approach to improvement. Scientific Bulletin online, 7. In http://www. lvivacademy.com/vidavnitstvo_1/visnik7/fail/paladij.pdf.

Ress, M. (November 13, 2017). SCCR 35 Day 1 at WIPO Standing Committee on Copyright and Related Rights: will the "YouTube treaty" progress? Knowledge Ecology International. In https://www.keionline.org/23519. 
Spreafico, F. (2011). No more dance for Baila! Kluwer Copyright Blog. In http://copyrightblog.kluweriplaw.com/2011/11/07/no-more-dance-forbaila/?doing_wp_cron=1597239719.0908250808715820312500.

Stefan, A. (2016). TV format: essence, content, legal protection. Copyright, 1, 49-58. In http://www.inprojournal.org/wp-content/uploads/2016/11/A-Shtefan-116.pdf.

Talimonchik, V. (2017). International protection of related rights in television broadcasting. Intellectual property. Copyright and related rights, 7, 25 - 32.

UkrInform. (2012). Ukrainian Studio "Kvartal -95" has signed an agreement with the Kazakh "Independent Television Channel" to sell the format of the entertainment project "Comedian Laughs". In https://www.ukrinform.ua/rubricsociety/1373142proekt_ukraiinskogo_shou_rozsmishi_komika_prodali_kazaham_1740637.html.

UNESCO. (1976). On the International Standardization of Statistics in the Field of Radio and Television: Recommendation. In https://atom.archives.unesco.org/a57e9.

UNESCO. (2001). Approaching intellectual property as a human right. Paris. In https://unesdoc.unesco.org/ark:/48223/pf0000125505.

United Kingdom. (1911). Copyright Act. In http://www.legislation.gov.uk/ukpga/Geo5/12/46/contents/enactedю.

United Nations. (1989). European Convention on Transfrontier Television. In https://rm.coe.int/168007b0d8.

United Nations. (1994). European Convention relating to questions on Copyright Law and Neighbouring Rights in the Framework of Transfrontier Broadcasting by Satellite. In https://www.coe.int/en/web/conventions/full-list//conventions/treaty/153.

United Nations. (2001). European Convention for the Protection of the Audiovisual Heritage. In https://www.coe.int/en/web/conventions/full-list//conventions/treaty/183.

United Nations. (2001). Protocol on the Protection of Television Products. In https://www.coe.int/en/web/conventions/full-list/-/conventions/treaty/184.

Vivarelli, N. (2011). BBC Worldwide, RAI win 'Baila!' suit. Variety. In https://variety.com/2011/tv/news/bbc-worldwide-rai-win-baila-suit$1118043411 /$.

Wagstaff, K. (May 1, 2015). Mayweather and Pacquiao: The Perfect Storm for Piracy? NBC News. In https://www.nbcnews.com/tech/social-media/pacquiaoperiscope-perfect-storm-piracy-n347866.

WIPO. (1886). Berne Convention for the Protection of Literary and Artistic Works. In https://www.wipo.int/treaties/ru/ip/berne/index.html.

WIPO. (1961). International Convention for the Protection of Performers, Producers of Phonograms, and Broadcasting Organizations. In https://www.wipo.int/publications/en/details.jsp?id=320\&plang=EN. 
Protection of Intellectual Property Rights in the Field of Television and the Internet

WIPO. (1974). Convention on the Distribution of Program-Carrying Signals Transmitted by Satellite (Brussels Convention). In

https://www.wipo.int/export/sites/www/treaties/en/documents/pdf/brussels.pdf.

WIPO. (1998). Standing Committee on Copyright and Related Rights (First SessionGeneva, November 2 to 10, 1998): Report. In http://www.wipo.int/edocs/mdocs/copyright/en/sccr_1/sccr_1_9.pdf

WIPO. (2011). The work the Standing Committee on Copyright and Related Rights (Fortieth $\left(20^{\text {th }}\right.$ Ordinary) Session, Geneva, September 26 to October 5, 2011: Report WO/GA/40/6. In http://www.wipo.int/edocs/mdocs/govbody/en/wo_ga_40/wo_ga_40_6.pdf.

WIPO. (2018). Protection of Broadcasting Organizations-Background Brief. In http://www.wipo.int/pressroom/en/briefs/broadcasting.html.

WIPO. (2020). Fifty-third (29th extraordinary) session of General Assembly. In https://www.wipo.int/meetings/ru/details.jsp?meeting_id=56324.

World Trade Organization. (1994). Trade-Related Aspects of Intellectual Property Rights. In https://www.wto.org/english/tratop_e/trips_e/trips_e.htm.

World Trade Organization. (1996). Copyright Treaty. In https://www.wipo.int/treaties/en/ip/wct/.

Zaitseva, A.V. (2018). Current issues of legal protection of television programs and programs as objects of intellectual property rights. Questions of culturology, 38, 199-207. https://doi.org/10.31866/2410-1311.34.2018.154071. 